\title{
Tożsamość Innego z perspektywy studentów pedagogiki
}

KEY WORDS

identity, Other, stereotype

\begin{abstract}
Orłowska Beata A., Tożsamość Innego z perspektywy studentów pedagogiki [The Identity of the "Other" from the Perspective of Students of Pedagogy]. Kultura - Społeczeństwo - Edukacja nr 1(7), 2015, Poznań 2015, pp. 61-74, Adam Mickiewicz University Press. ISBN 978-83-232-2944-5. ISSN 2300-0422

In the article, pedagogy students' attitutude towards identity "Other" has been discussed. Attention has been paid to the role of stereotype in shaping approach to identity "Other" students pedagogy. The importance of knowledge and education of future teachers about stereotypes, identity, and "Other" in the perception of the "Other".
\end{abstract}

Procesy, które zaszły na świecie w ostatnich pięćdziesięciu latach, pokazały, że również w nas samych muszą zaistnieć zmiany. Mogą one dotyczyć wielu różnych obszarów, ale chyba jednym $\mathrm{z}$ najważniejszych jest podejście do Innych, których spotykamy na swojej drodze. Dzięki rozwojowi komunikacji świat bardzo się skurczył. Często przemieszczamy się nawet bardzo daleko w bardzo krótkim czasie. Ale skoro my to robimy, robią to również Inni. Czasami są tylko „na chwilę" u nas, ale czasami pozostają na dłużej. To tu zaczynają swoje życie, uczęszczają do szkoły, pracują, mają dzieci... Spotkania z nimi to nie tylko wymiana myśli i doświadczeń, ale również wymiana kultury, spotkanie różnych religii, czyli wzajemne poznawanie się.

Interesujące jest, jak my widzimy Innych, jak ich traktujemy, jak się do nich odnosimy. Poprzez kontakty uczymy się siebie nawzajem i jest to o tyle istotne, że ucząc się od najmłodszych lat, później na tym doświadczeniu budujemy nasze stereotypy. Sposób, w jaki rozumiemy i jak widzimy Innych, to szczególnie ważny i delikatny obszar naszego życia. Również studenci kierunków pedagogicznych muszą posiadać odpowiednią wiedzę na ten temat, gdyż na swojej drodze zawodowej zetkną się z dziećmi i ich rodzicami pochodzącymi z różnych kultur i religii. 


\section{Czym jest stereotyp?}

Mieszanie się kultur i religii może być źródłem wielu stereotypów, które mają wpływ na postrzeganie innych. Warto jest więc wspomnieć trochę o stereotypach, gdyż często się nimi posługujemy, ale czy znamy ich znaczenie? Według Stownika socjologii i nauk społecznych stereotyp i stereotypizacja to

termin wywodzący się z języka greckiego (stereos - stężały, typos - znak), używany pod koniec XVIII w. jako termin techniczny określający robienie z masy papierowej kopii czcionek drukarskich. Pojęcie stereotypu rozwinął amerykański dziennikarz W. Lippmann. (...) Terminowi temu nadaje się zazwyczaj znaczenie pejoratywne, w przeciwieństwie do socjologicznego procesu typizacji. (Marshall, 2005: 360)

W Encyklopedii pedagogicznej XXI wieku czytamy, że stereotyp to

mocno zakorzenione pozytywne albo negatywne wyobrażenie osób, kategorii i grup społecznych, wydarzeń lub przedmiotów, które opiera się na powierzchownych obserwacjach i logicznie nieuprawnionych uogólnieniach cech tego, czego dotyczy, i utrzymuje się mimo nowych doświadczeń, ponieważ łączy się z dużym zaangażowaniem uczuciowym danej osoby. (Pilch, 2006: 990)

W konsekwencji może to oznaczać tworzenie się w świadomości ludzi pewnych wyobrażeń, które mogą nie do końca właściwie odzwierciedlać rzeczywistość.

Obecność stereotypów w naszym życiu jest naturalna i nie da się ich uniknąć. Jednak trzeba mieć świadomość, że myślenie stereotypowe dotyczy zarówno ludzi, jak i rzeczy, czy występujących wokół nas zjawisk.

O ile jednak nasze wyobrażenie o rzeczy znacząco nie wpłynie na stosunek do przedmiotu, o tyle negatywne (bądź pozytywne) emocje wobec Niemców czy warszawiaków mogą wpłynąć na nasze osobiste kontakty z sąsiadami zza granicy bądź osobami pochodzącymi ze stolicy. (Czerniejewska, 2006: 262)

Konsekwencją takiego podejścia może być to, że „ludzie dostrzegają więc to, co potwierdza posiadany przez nich stereotyp, i z kolei nie widzą tego, co jemu przeczy. Dlatego stereotypy nie tylko upraszczają, ale i fałszują postrzeżenia" (Pilch, 2006: 990). Pełna wiedza studentów jako przyszłych nauczycieli na temat występowania różnych stereotypów pomoże w przyszłości zrozumieć otaczający świat i bardziej się na niego otworzyć.

Wartość stereotypów ma swoje przełożenie również między innymi na procesy poznawczo-intelektualne i osobowościowo-tożsamościowe (Pilch, 2006: 999). Jest to o tyle istotne, że jak dowodzą badania, 
wyobrażenia zarówno o grupie własnej, jak i o obcych są już wyraźnie sformułowane w świadomości dzieci. Przyjmuje się je wraz z językiem, który pełni tu ważną rolę, pod wpływem rodziny, rówieśników, szkoły i literatury. Każdy człowiek, żyjąc od urodzenia w pewnej kulturze, przyswaja sobie normy zachowań i moralności, ale również stereotypy danej grupy etnicznej, kulturowej, społecznej. (Czerniejewska, 2006: 263-264)

Oznacza to, że od najmłodszych lat, również przez proces edukacji, przekazujemy je kolejnym pokoleniom. To dzięki procesowi socjalizacji stereotypy przekazywane są kolejnym członkom grupy. A to oznacza, zdaniem I. Czerniejewskiej, że

istnieje możliwość wpływania na powstawanie i kształtowanie się stereotypów. Wraz z nowymi doświadczeniami życiowymi, zdobytą wiedzą i umiejętnościami nabywamy lub zmieniamy poglądy, opinie i wyobrażenia o świecie. Tak samo możemy wpływać na kształtowanie się stereotypów. (Czerniejewska, 2006: 270)

Podejście takie oznacza, że jesteśmy w stanie zmieniać obraz stereotypu w umyśle jednostek i grup. Trzeba tylko nad tym popracować. Oczywiście nie jest to zadanie łatwe, ale nie jest też niemożliwe. Wystarczy tylko wyznaczyć obszary pracy, które umożliwią zmiany $\mathrm{w}$ stereotypowym postrzeganiu świata i innych. Praca ta powinna być wykonana w kilku różnych obszarach, które nie są odosobnionymi częściami, lecz wzajemnie uzupełniającymi się działaniami. Do głównych z nich zaliczyć należy przede wszystkim:

- Dostarczanie wiedzy: o grupach i zjawiskach objętych stereotypami i uprzedzeniami, tłumaczenie mechanizmów działania stereotypów, ich źródeł i funkcji;

- Umożliwienie doświadczenia: z grupami objętymi stereotypami, integracja i wspólne działanie z tymi grupami, stwarzanie sytuacji umożliwiających zrozumienie uczuć innych, odczucia odmienności;

- Ćwiczenie umiejętności: identyfikowania stereotypów, uprzedzeń, dostrzegania pozytywnego zróżnicowania między ludźmi, krytycznego spojrzenia na prezentowane przez media (i innych ludzi) opinie i postawy;

-Wsparcie rozwoju osobistego: pomoc w określeniu własnej tożsamości osobistej i społecznej, samoświadomość ograniczeń i umiejętność przekraczania stereotypowego myślenia;

- Dostarczanie wzorów: przybliżanie postaw prospołecznych, uczenie współpracy i negocjacji w grupie, okazywanie szacunku dla innych, odmiennych kulturowo, rozbudzanie ciekawości świata. (Czerniejewska, 2006: 270)

Patrząc z takiej perspektywy, trzeba też mieć świadomość, że stereotyp wymaga istnienia nas i innych. Tylko wtedy może nastąpić proces rozpoznawania własnej tożsamości na tle tożsamości innych, tych należących do odrębnej grupy. Dlatego też nie można rozpatrywać zagadnienia tożsamości zarówno własnej, jak i innych, bez uwzględnienia zagadnienia stereotypu. 


\section{Tożsamość Swoich i Obcych}

Każdy z nas przez całe swoje życia poszukuje siebie. Próbuje odpowiedzieć sobie na pytanie: kim jestem? Poszukuje swojej tożsamości. Ale to poszukiwanie siebie zawsze odbywa się na tle widzenia innych. Anthony Giddens podkreśla przy tym, że na kształt tożsamości wpływ ma wiele czynników. To właśnie one wraz z socjalizacją wykształcają u człowieka jego tożsamość (Kawula, 2008: 33-34). Czym więc jest tożsamość i jak przebiega jej kształtowanie we współczesnym świecie?

Tożsamość jako zagadnienie interdyscyplinarne jest w kręgu zainteresowania wielu różnych nauk (Karkowska, Skalski, 2010: 61). Z języka łacińskiego oznacza identyczność i ciągłość. W potocznym użyciu zaczęto się nim posługiwać dopiero w XX wieku. Jak podkreśla Stanisław Kawula, dyskusje dotyczące tożsamości toczyły się w dwóch kierunkach - psychodynamicznym i socjologicznym (Kawula, 2008: 402). Ale to Touraine podjął próbę bardziej wnikliwej analizy pojęć występujących $\mathrm{w}$ teorii socjologicznej. Konsekwencją takiego podejścia był przede wszystkim

złożony wzór grupowych afiliacji jednostki w społeczeństwie współczesnym, „rozmyte” granice kategoryzacji społecznych, szybkie zmiany sytuacji życiowych ludzi, ich zmieniające się interesy i sympatie ideologiczne, wszystko to - zdaniem Touraine’a - nakazywało zajmowanie się w socjologii procesami „powstawania” aktora społecznego. (Bokszański, 2007: 24)

Na tym tle ważnym zadaniem okazało się kształtowanie własnej tożsamości.

Obecnie tożsamość traktuje się jako pewną kategorię, która zajmuje się opisem sytuacji jednostki w świecie. Erik Erikson zaproponował nowe rozumienie pojęcia tożsamość, które zostało wykorzystane przez socjologię. Współcześnie właśnie na bazie jego pojęcia interpretuje się zachowanie i wchodzenie w relację człowieka z różnymi grupami i społecznościami (Kawula, 2008: 34).

Szybkie i dynamiczne zmiany zachodzące we współczesnym świecie powodują, że nie jest łatwo młodym ludziom zarówno określić własną tożsamość, jak również tożsamość innych czy móc potrafić odnieść się obiektywnie do tożsamości innych. Zdarza się, że

ludzie przez całe życie szukają odpowiedzi na wiele dręczących pytań dotyczących ich życia, ich osobowości, ich tożsamości jednostkowej, społecznej, narodowej. Pytają sami siebie: kim jestem? Jaki jest cel mojego życia? Jak mam traktować swoje pochodzenie, swoją kulturę, swoją tradycję?. (Kawula, 2008: 37)

Patrząc $\mathrm{z}$ tej perspektywy na tożsamość, warto rozpatrywać ją w dwóch zasadniczych obszarach - osobistym, czyli jednostkowym, i społecznym. Tożsamość jednostkowa (osobista) podkreśla odrębność i swoistą indywidualność 
jednostki w stosunku do innych ludzi. Na tym etapie człowiek zaczyna rozumieć, co to znaczy być sobą. Umożliwia to wykształcenie stosunku do otaczającego nas świata i środowiska społecznego. To dzięki ciągłym interakcjom ze światem zewnętrznym stajemy się sobą (Kawula, 2008: 52). To właśnie interakcje ze światem zewnętrznym uzmysławiają nam, kim jesteśmy.

Tożsamość społeczna powiązana jest z tożsamością jednostkową. Jej zakres obejmuje cechy, jakie jednostce przypisują inni ludzie. Cechy te rozumiane są często jako pewne wyznaczniki wskazujące na to, kim jest ta jednostka. Oznacza to, że jeden człowiek może mieć bardzo dużo różnych tożsamości, na przykład jest jednocześnie matką, pracownicą, katoliczką, czy ojcem, dziadkiem, urzędnikiem itp. Posiadanie wielu różnych tożsamości społecznych wiąże się z pełnieniem wielu różnych funkcji społecznych. Oznacza to, że tożsamości społeczne mają wymiar zbiorowy, ponieważ jednostki upodabniają się do innych ludzi. Opierają się między innymi na wspólnych celach, różnych wspólnych doświadczeniach czy normach i wartościach (Kawula, 2008: 52).

\section{Tożsamość Innego w opinii studentów pedagogiki}

Roman Leppert zwraca uwagę, że młodość to „kategoria wiekowa, obejmująca osoby aktywnie poszukujące własnej tożsamości”; „charakteryzująca się poszukiwaniem własnej tożsamości”; młodzi ludzie „poszukują swej tożsamości”; „szukają, próbują odnaleźć własną tożsamość” (Leppert, 2010: 16). Maria Kielar-Turska, dokonując charakterystyki okresu dorastania, wyróżnia różne elementy rozwoju, w tym rozwój tożsamości (Leppert, 2010: 22). Obok rozwoju motorycznego, dojrzewania biologicznego i rozwoju psychoseksualnego jest to jeden z ważniejszych etapów naszego rozwoju, jakże ważny dla ukształtowania w pełni jednostki. Te i wiele innych, podobnych poglądów pokazuje, że jest to okres dużej dynamiki zmian, a w dzisiejszym, zglobalizowanym świecie wiele osób ma problemy z samookreśleniem. Jako ludzie wszyscy poszukujemy swojej tożsamości. Aby zrozumieć siebie, konieczne jest jej określenie i sprecyzowanie. Dotyczy to zarówno tożsamości jednostkowej (osobowej), jak też tożsamości społecznej czy narodowej (Kawula, 2008: 39). Na obraz naszej tożsamości wpływają nie tylko elementy strukturalne, odziedziczone genetycznie po przodkach. Istotny wpływ mają też elementy nabyte, szczególnie w środowisku rodzinnym i pozadomowym. Zaliczane są do nich następujące elementy dynamiczne:

- samoocena;

- mechanizmy przystosowujące:

- destrukcji (ucieczka i odcięcie się od wartości przekazywanych przez pokolenia), 
- transformacji (kierowanie się wartościami nowo nabytymi w nowych warunkach),

- mechanizm syntetyzujący (asymilacja bez wynarodowienia). (Kawula, 2008: 34)

Odnosząc wspomniane zagadnienie do analizy współczesnego polskiego pokolenia młodzieży, często zwraca się uwagę na istotną rolę transformacji ustrojowej, która była przełomem politycznym i społecznym w Polsce i stała się dla współczesnych badaczy pewnym czasem odniesienia. W okresie tym młodzi ludzie wchodzili w dorosłość. To wtedy, w nowych warunkach ustrojowych, kształtowała się ich tożsamość. Istnieje wiele odniesień do tego okresu. Warto jest wspomnieć o kilku, aby pokazać różne ujęcia, między innymi Witolda Września, Janusza Czapińskiego i Marii Zielińskiej.

Witold Wrzesień na określenie młodzieży tego okresu używał stwierdzenia Pokolenie Końca Wieku. Zaliczał do niego tak zwane subpokolenia: Pokolenie Dzieci Transformacji oraz pokolenie Maruderów Końca Wieku (Kawula, 2008: 79-80).

Zdaniem Janusza Czapińskiego często młodzi ludzie uważają, że są niezrozumiani przez dorosłych i rówieśników. Może się to wyrażać między innymi występowaniem barier komunikacyjnych czy negatywnego stosunku do otoczenia.

Tego rodzaju zaburzenia zazwyczaj utożsamiane są z osobowością borderline, niestabilnością psychiczną, zmiennymi nastrojami, podejmowaniem prób samobójczych czy pokazowych aktów samookaleczenia (np. subkultura Emo). (...) Przejawami osobowości borderline bywają również multiplikacje osobowości, tworzenie klonów w świecie wirtualnym, a następnie przenoszenie ich do sfery rzeczywistej, tzw. realu, przez jej wirtualizowanie czy mitologizowanie. Borderline jest prawie zawsze reakcją na wygórowane oczekiwania otoczenia, wyścig i konkurencję, a także na doznawaną frustrację potrzeb afiliacji i poczucia bezpieczeństwa. (Kawula, 2008: 790)

Odpowiedzią na w/w propozycje jest podział zaproponowany przez Marię Zielińską, która podzieliła współczesne pokolenie młodzieży na:

- pokolenie historycznej nadziei i codziennego ryzyka; to osoby, które w 1989 r. miały osiemnaście lat, wchodzące w dorosłość równolegle z wydarzeniami Okrągłego Stołu; ich dorastanie przebiegało wokół dekompozycji dotychczasowego systemu społecznego i politycznego;

- pokolenie dzieci stanu wojennego; to osoby urodzone w latach 80. (Kawula, 2008: 78)

Takie podejście do interpretacji tożsamości sugeruje, że mogą się pojawić problemy w samookreśleniu się młodych ludzi. Może to mieć również wpływ na postrzeganie tożsamości Innych. Skoro nie potrafią sami określić siebie, to nie będą potrafili też określić tożsamości Innych. 
W celu zbadania postrzegania swoich i obcych zapytano studentów pierwszego roku pedagogiki o wskazanie cech Swoich i Obcych. W badaniu zastosowano metodę sondażu diagnostycznego, której zgodnie z założeniami M. Łobockiego

podstawową funkcją jest gromadzenie informacji o interesujących badacza problemach w wyniku relacji słownych osób badanych, nazywanych respondentami. (...) W przypadku odpowiedzi pisemnych przybiera ona formę ankiety czy - inaczej mówiąc - badań ankietowych... (Łobocki, 2006: 243)

W celu lepszego zorientowania się $\mathrm{w}$ tendencjach postrzegania przez studentów swoich i obcych podczas badań zastosowano w ankiecie audytoryjnej (Łobocki, 2006: 260) pytania otwarte, które dały badanym całkowitą swobodę w prezentacji swoich poglądów na charakterystyczne cechy Swoich i Obcych. Takie przeprowadzenie procesu badawczego umożliwiło też badanym dowolne poruszanie się w obszarze cech występujących w obu grupach. Badani mieli swobodę w wyrażaniu cech, zwracając przy tym uwagę na dziesięć cech najbardziej (ich zdaniem) charakterystycznych. Taki charakter badań pozwolił na zbudowanie pewnego modelu najbardziej charakterystycznych cech (najczęściej wymienianych) przez studentów pierwszego roku pedagogiki. Poniżej zaprezentowane zostały wyniki badań wstępnych, które obecnie będą pogłębiane i bardziej uszczegóławiane w celu zbudowania modelu cech swoich i obcych.

Tabela 1. Cechy Swoich w opinii studentów pedagogiki. Źródło: badania własne luty 2015 r.

\begin{tabular}{|c|l|}
\hline Liczba wyborów & \multicolumn{1}{|c|}{ Cecha charakterystyczna dla Swoich } \\
\hline 22 & Wspólny język - polski \\
\hline 19 & Podobne zainteresowania \\
\hline 14 & Taka sama kultura \\
\hline 9 & $\begin{array}{l}\text { Te same tradycje } \\
\text { Religijność } \\
\text { Przyjacielskość }\end{array}$ \\
\hline 8 & $\begin{array}{l}\text { Te same wartości } \\
\text { Te same cele } \\
\text { Ten sam kolor skóry } \\
\text { Szczerość } \\
\text { Poczucie humoru }\end{array}$ \\
\hline 7 & Otwartość \\
\hline 6 & Wspólne z moimi poglądy \\
\hline 5 & $\begin{array}{l}\text { Optymizm } \\
\text { Z tego samego miejsca zamieszkania } \\
\text { Lubiący się bawić, rozrywkowy, towarzyski }\end{array}$ \\
\hline
\end{tabular}




\begin{tabular}{|c|c|}
\hline Liczba wyborów & Cecha charakterystyczna dla Swoich \\
\hline 4 & $\begin{array}{l}\text { Te same normy, zasady } \\
\text { Wyrozumiałość } \\
\text { Można mieć do niego zaufanie } \\
\text { Otaczający mnie na co dzień } \\
\text { Koledzy, koleżanki z uczelni } \\
\text { Członek określonego narodu } \\
\text { Pomocność }\end{array}$ \\
\hline 3 & $\begin{array}{l}\text { Miły } \\
\text { Uśmiechnięty } \\
\text { Pewny siebie (przebojowy) } \\
\text { Podobny do mnie }\end{array}$ \\
\hline 2 & $\begin{array}{l}\text { Obchodzenie świąt } \mathrm{w} \text { tym samym czasie } \\
\text { Zbliżone cechy charakteru } \\
\text { Rodzinny } \\
\text { Prawdomówny } \\
\text { Bliska znajomość } \\
\text { Odważny } \\
\text { Ta sama historia } \\
\text { Otwartość } \\
\text { Wspólne terytorium } \\
\text { Patriotyzm }\end{array}$ \\
\hline 1 & $\begin{array}{l}\text { Sympatyczny } \\
\text { Pozytywny } \\
\text { Z pasją } \\
\text { Bliskość przestrzenna } \\
\text { Znajomość realiów życia } \\
\text { Łatwość kontaktów } \\
\text { Kreatywny } \\
\text { Jest sobą } \\
\text { Niereligijny } \\
\text { Tolerancyjny } \\
\text { Lojalny } \\
\text { Rówieśnik } \\
\text { Przynależność do grupy } \\
\text { Podobne wychowanie }\end{array}$ \\
\hline
\end{tabular}

Prezentowane powyżej wybory studentów pedagogiki wskazują, że poszukiwanie własnej tożsamości jest wyraźnie widoczne. Wielość i różnorodność wskazywanych cech od cech charakteru, wyglądu czy przynależności terytorialnej i grupowej po charakterystyczne sposoby zachowania wskazują, że to poszukiwanie nadal trwa. 
Tabela 2. Cechy Innych (Obcych) w opinii studentów pedagogiki. Źródło: badania własne luty $2015 \mathrm{r}$.

\begin{tabular}{|c|c|}
\hline Liczba wyborów & Cechy charakterystyczne Innych \\
\hline 18 & Inny język \\
\hline 11 & Inna religia, wyznanie \\
\hline 10 & Inny kulturowo \\
\hline 8 & Inny kolor skóry \\
\hline 7 & Fałszywy \\
\hline 6 & Agresywny \\
\hline 5 & Inna narodowość \\
\hline 4 & $\begin{array}{l}\text { Pesymista } \\
\text { Zamknięty w sobie } \\
\text { Egoista }\end{array}$ \\
\hline 3 & $\begin{array}{l}\text { Ktoś mający inne zainteresowania } \\
\text { Wulgarny } \\
\text { Brak porozumienia } \\
\text { Skąpy } \\
\text { Mieszkańcy innych krajów }\end{array}$ \\
\hline 2 & $\begin{array}{l}\text { O innej orientacji seksualnej } \\
\text { Nieznajomi } \\
\text { O innych cechach charakteru od własnych } \\
\text { Gburowaty } \\
\text { Wrogo nastawiony do innych ludzi } \\
\text { Smutny } \\
\text { Budzący poczucie niepewności, niebezpieczeństwa, lęku } \\
\text { Nudny } \\
\text { Brak wspólnych zainteresowań } \\
\text { Kłamliwy } \\
\text { Inne poglądy }\end{array}$ \\
\hline 1 & $\begin{array}{l}\text { Przeciwieństwo swoich } \\
\text { Nie towarzyski } \\
\text { Zakryte twarze } \\
\text { Jedzący psy } \\
\text { Więzień } \\
\text { Ktoś z innego miejsca zamieszkania } \\
\text { Z kim przebywam, lecz nigdy z nim nie rozmawiam } \\
\text { Samotnik } \\
\text { Ma inne tradycje, zwyczaje } \\
\text { Brak bliższej znajomości } \\
\text { Z brakiem chęci do życia } \\
\text { Zamknięty w swoich ideach } \\
\text { Fanatyk } \\
\text { Trudność kontaktów }\end{array}$ \\
\hline
\end{tabular}




\begin{tabular}{|l|l|}
\hline Liczba wyborów & \multicolumn{1}{|c|}{ Cechy charakterystyczne Innych } \\
\hline & Krytyczny \\
& Nachalny \\
& Nie prawdziwy \\
& Religijny \\
& Leniwy \\
& Brak tolerancji \\
& Brak lojalności \\
& Nieśmiały \\
& Odrębność \\
& Ponury \\
& Nie potrafiący słuchać \\
& Niewdzięczny \\
\hline
\end{tabular}

Dokonując porównania, jakimi cechami charakteryzują się Obcy w opinii studentów pierwszego roku pedagogiki, wyraźnie obserwuje się podobne wybory dotyczące języka - ten sam lub inny (pierwsza pozycja wyboru) i kultury - taka sama lub inna (trzecia pozycja wyboru). Pozostałe wskazania cech charakterystycznych dla Obcych pokazują, że w większości są to cechy negatywne. Takie postrzeganie charakterystycznych cech Innych może świadczyć o braku wiedzy na temat innej narodowości, kultury czy tradycji. Wskazuje też na pewien powierzchowny sposób patrzenia na Innych.

Tabela 3. Stosunek studentów pedagogiki do Innych. Źródło: badania własne luty 2015 r.

\begin{tabular}{|l|l|}
\hline \multirow{2}{*}{ Liczba wyborów } & \multicolumn{1}{c|}{ Stosunek do Innych } \\
\cline { 2 - 2 } & Ciekawość \\
\hline 18 & Tolerancja \\
\hline \multirow{2}{*}{13} & $\begin{array}{l}\text { Szacunek } \\
\text { Irytacja } \\
\text { Złość }\end{array}$ \\
\hline \multirow{2}{*}{11} & Dystans \\
\hline 10 & Strach \\
\hline \multirow{2}{*}{9} & $\begin{array}{l}\text { Obojętność } \\
\text { Zdziwienie } \\
\text { Ostrożność }\end{array}$ \\
\hline \multirow{2}{*}{8} & Radość \\
\hline 7 & Uśmiech \\
\hline 6 & $\begin{array}{l}\text { Akceptacja } \\
\text { Zainteresowanie } \\
\text { Niepewność }\end{array}$ \\
\hline & Zrozumienie \\
\hline
\end{tabular}




\begin{tabular}{|c|c|}
\hline Liczba wyborów & Stosunek do Innych \\
\hline & $\begin{array}{l}\text { Niechęć } \\
\text { Wstręt }\end{array}$ \\
\hline 4 & $\begin{array}{l}\text { Nieufność } \\
\text { Otwartość }\end{array}$ \\
\hline 3 & $\begin{array}{l}\text { Sympatia } \\
\text { Chamstwo } \\
\text { Wrogość } \\
\text { Podziw } \\
\text { Zachwyt } \\
\text { Nieśmiałość } \\
\text { Podejrzliwość }\end{array}$ \\
\hline 2 & $\begin{array}{l}\text { Lubię nowych } \\
\text { Empatia } \\
\text { Nie oceniam do czasu aż poznam daną osobę } \\
\text { Niepewność } \\
\text { Pozorna ocena } \\
\text { Kategoryzacja } \\
\text { Płacz } \\
\text { Smutek } \\
\text { Zażenowanie } \\
\text { Chęć do rozmowy } \\
\text { Chęć lub niechęć przebywania } \\
\text { Skrępowanie } \\
\text { Obawa }\end{array}$ \\
\hline 1 & $\begin{array}{l}\text { Życzliwość } \\
\text { Pierwsze wrażenie - krytyka bądź zachwyt } \\
\text { Wyrozumiałość } \\
\text { Neutralny } \\
\text { Wejść w jego historię } \\
\text { Zachowanie minimalnego dystansu } \\
\text { Uprzejmość } \\
\text { Rozczarowanie }\end{array}$ \\
\hline
\end{tabular}

Po analizie cech charakterystycznych dla Swoich i Obcych próbowano ustalić, jaki jest stosunek studentów pedagogiki do Innych. Studenci odnieśli się do tego zagadnienia przez pryzmat emocji, jakie ich zdaniem towarzyszą im podczas poznawania Innych. Najczęściej wymienianą cechą była ciekawość. To ona powoduje, że studenci zwracają uwagę na Innych. Ktoś inaczej ubrany, inaczej wy- 
glądający, inaczej zachowujący się to ten, który posiada inną tożsamość od naszej - podkreślali. Stąd ciekawość - kto to jest? Co robi? Jak wygląda i dlaczego? Ale jednocześnie najrzadszym odczuciem spośród wymienianych przez badanych studentów była między innymi życzliwość w stosunku do Innych. W większości wyborów pojawiła się też między innymi tolerancja i szacunek. Jest to ważny kierunek do podjęcia dyskusji na temat stosunku do inności i kształtowania postawy otwartości na inność przez pryzmat cech pozytywnych.

Z przeprowadzonych badań wstępnych wyraźnie wynika, że na poziomie początkowego okresu studiów wyższych ważnym elementem w procesie kształtowania podejścia do tożsamości Innych jest edukacja. Ważnym etapem studiowania na pewno okazuje się kształtowanie odpowiedniego podejścia do inności przez pryzmat poznawania stereotypów i uprzedzeń w stosunku do innych grup i osób. A dzięki poznaniu tych stereotypów dokonywanie zmiany w patrzeniu na Innych. Oczywiście nie jest to zadanie łatwe nawet na miarę współczesnego świata.

$\mathrm{Z}$ wymienionych powyżej współczesnych podziałów tożsamości, występujących wśród młodzieży, wyodrębnia się istotna różnica w kształtowaniu się tożsamości współczesnego młodego człowieka w stosunku do poprzednich pokoleń. Poprzednie pokolenia, w których obserwowaliśmy kształtowanie się tożsamości, miały z kim walczyć, miały o co walczyć, czyli miały cele, które pomagały im kształtować tożsamość. Można nawet śmiało stwierdzić, że cele te wskazywały drogę kształtującej się tożsamości. A jak jest obecnie? Obecnie stwierdza się, że

skoro nie ma z czym walczyć, wokół jest tylko pustka, brak wiążących niegdysiejsze pokolenia wspólnych, trudnych doświadczeń, pozostaje jedynie dążenie do przyjemności i tymczasowego, krótkotrwałego zaspokojenia potrzeb materialnych przejawiających się w tendencji zwanej brandingiem tożsamości, a realizowanej przez dążenie do nabywania i posiadania rzeczy mających odpowiednie logo, metkę, spełniających kryteria mody i przynależnych do najnowszych trendów. (Kawula, 2008: 84)

Czy tak właśnie ma wyglądać tożsamość młodego pokolenia XXI wieku? Kim są współcześni młodzi ludzie? Jak określają siebie? Jak widzą Innych? Te i wiele innych pytań, które pojawiły się w wyniku wstępnych badań studentów, pokazały, że współcześnie jeszcze bardziej uważnie należy zająć się młodymi ludźmi, wchodzącymi w dorosłe życie, wspierając ich w odpowiedzi na nurtujące ich pytania o tożsamość, czyli w pierwszej kolejności w pytaniach o siebie. Rolą nauczycieli, wychowawców i rodziców jest zadbanie, by kolejne pokolenia, kształtując swoją tożsamość i jednocześnie kształtując odpowiedni stosunek do tożsamości Innego, potrafiły odpowiedzieć na te podstawowe pytania przede wszystkim sobie. 


\section{Literatura}

Bokszański Z. (2007). Tożsamości zbiorowe. Warszawa.

Czerniejewska I. (2006). O stereotypie kulturowym, czyli jak widzimy innych. [W:] A.W. Brzezińska, A. Hulewska, J. Słomska (red.). Edukacja regionalna. Warszawa.

Karkowska M., Skalski T. (2010). Kultura, socjalizacja, tożsamość. Kraków.

Kawula S. (2008). Wielorakość kultur w dyskursie pedagogiki społecznej. Olsztyn.

Leppert R. (2010). Młodzież - świat przeżywany i tożsamość. Kraków.

Łobocki M. (2006). Metody i techniki badań pedagogicznych. Kraków.

Marshall G. (red.). (2005). Stownik socjologii i nauk społecznych. Warszawa.

Pilch T. (red.). (2006). Encyklopedia pedagogiczna XXI wieku. Warszawa.

\section{The identity of the "Other" from the Perspective of Students of Pedagogy}

\section{Summary}

The problem of the students of the pedagogics finding the others has been presented in the article. Terms of a stereotype and an identity have been defined. On the basis of the aforementioned, the issue of the Other's identity has been found. In the present days, perceiving the Other, not only by the students of the pedagogics plays a significant role in perceiving other countries and nations.

The first part is solely devoted to the term of a stereotype. A short historical background and its range are given. Quality of a stereotype and its influences are presented. Going further, the possibility of changing attitude towards a stereotype is touched upon, pointing out to gaining knowledge, experiences and practicing some skills, the support of personal development and providing with examples to follow.

In the second part, self-identity and the identity of the Others are provided. The term identity is covered and the context of self and the Other's. the problem of one's struggle to fin down identity has been highlighted. So were the following questions: Who am I? How should 1 find my ethnics, my culture and habits? Various fields of identity are also presented: social, entity, national and others.

The third part features results of the pilotage studies conducted in order to learn about students opinions concerning the identity the Other. The studies reveal that education is of high importance in terms of placing a found to the process of attitude towards identity of the Others. An important stage of education is founding proper attitude to the Others in the prism of getting familiar with stereotypes and prisms regarding other groups and people. Thanks to getting familiar with stereotypes, there is a possibility to change one's perception on the other people. This is not as easy as it may sound even for the nowadays world.

Having a quick glance abovementioned present diversity of identities occurring among the youth, we may notice a major distinction in the process of founding identity of present youth man with regards to previous generations. The previous generations, in which we noticed founding the identities, had a lot to fight for, which means they had aims. This helped them to found the identity. We can assume that those aims were crucial to found an identity. How this relates to the present 
days? Nowadays it is said „if you don't have anyone to fight, there's a void, no hardships. There is only pursuit of pleasure and of short lasting material needs, which can be seen in the so called branding identity tendency where people purchase materials with logos that are trendy".

So, is this the way the current youth identity looks like? Who are the present young people? How they define themselves? These and more questions appear in the results of an initial studies and put an emphasis on issue - we should focus more on taking care of the youth turning into adults, helping them with identity problems, most importantly questions about themselves. Role of the teachers, lectures and parents is to make sure that the next generations should be able to answer questions themselves while founding their identity and founding attitude to the other's identity.

After analysis of all characteristic features for Self and Other, there was an attempt to figure out pedagogics students attitude towards the Others. Students related to this by prism of emotions while meeting Others. The most common feature was curiosity, which is the reason why students pay attention to the Others. Someone dressed and looking in a different way, behaving in a different way - who possesses other identity than ours - students highlighted. That's why curiosity occurs - who is that? What does he or she do? How does he or she looks like and why? Moreover, the least common feeling was sincerity towards the Others. On the other hand, more common were tolerations and respect. It i san important direction to start a discussion concerning attitude towards the Others and founding base to openness to the Others by prism of positive features. 